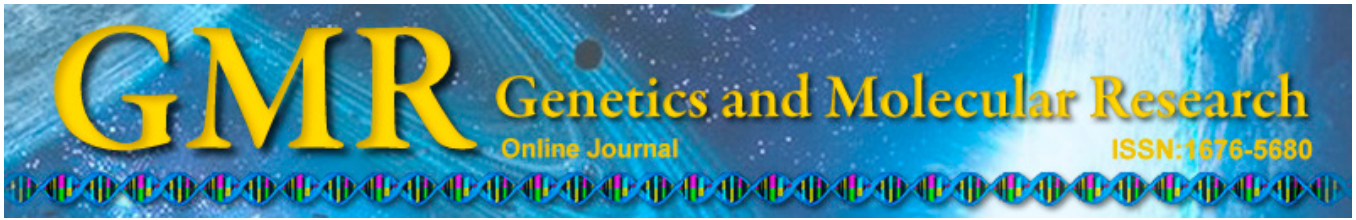

\title{
Genetic diversity in Tunisian populations of faba bean (Vicia faba L.) based on morphological traits and molecular markers
}

\author{
I.Z. Backouchi, M. Aouida, N. Khemiri and M. Jebara \\ Laboratoire des Légumineuses, Centre de Biotechnologie Borj Cedria, \\ University Tunis El Manar, Hammam Lif, Tunisie \\ Corresponding author: I.Z. Backouchi \\ E-mail: ziadiimtiez@yahoo.fr
}

Genet. Mol. Res. 14 (3): 7587-7596 (2015)

Received April 8, 2014

Accepted February 19, 2015

Published July 13, 2015

DOI http://dx.doi.org/10.4238/2015.July.13.2

\begin{abstract}
Genetic diversity within Vicia faba L. is key to the genetic improvement of this important species. In this study, morphological traits and RAPD molecular markers were used to assess the levels of polymorphism across 12 Tunisian populations, three major and nine minor from different locations. Analysis of morphological traits indicated that the three major populations showed significant differences and the nine minor populations exhibited considerable variation for most traits. The grain yield of the Alia population could be increased by inoculation. Of the seven primers tested, it was clear that the Cs 12 primer would be recommend for genetic diversity analysis of $V$. faba Within population genetic diversity exhibited $94 \%$ of total diversity. Intra-population genetic diversity $\left(H_{\mathrm{S}}\right)$ was 0.16 , which was clearly higher than between population genetic diversity $\left(D_{\mathrm{ST}}=0.06\right)$ UPGMA showed a high level of genetic variation between major and minor populations of $V$. faba L. Particularly the minor populations showed a high level of diversity and was divided into two subclusters. Ltaifia was separated from the other populations. In addition to a high grain yield,
\end{abstract}


these populations showed the lowest Nei and Shannon indices $(H=$ 0.08 and $I=0.13$ ) justifying their homogeneity. For these reasons, these cultivars can be considered a selected population. However, the Takelsa population showed the highest Nei and Shannon indices $(H=0.13$ and $I=0.21$ ), indicating that this population was the most heterogeneous, which is interesting for breeding programs.

Key words: Genetic diversity; morphological traits; RAPD; Tunisian populations; UPGMA analysis; Vicia faba L.

\section{INTRODUCTION}

Faba bean (Vicia faba L.) is one of the most important legumes, and it is extensively cultivated in the world. It not only provides an important source of human dietary protein, but is also a good source for the feed market (Gong et al., 2011).

Due to its partial cross-pollination, there are various faba bean varieties and they are highly heterogeneous, which makes the conservation of genotype resources more expensive and difficult (Duc et al., 2010).

However, despite its long history of cultivation and economic importance, there have been few studies about the diversity of faba beans (Gong et al., 2011).

Morphological studies are used to study multiple characters at the same time, to help discriminate heterogeneous populations, and they are vital tools to predict mechanisms of spread and dispersal of species (Benor et al., 2012).

Morphological characterization of plant species is mainly used to conduct a thorough investigation of genetic diversity in germplasm collections, contributing valuable information for breeding programs and conservation strategies for taxa of concern (Benor et al., 2012).

One of the most extensively used molecular markers is RAPD, which has been applied to address genetic diversity issues in plants (Vilanova et al., 2001; Gichuki et al., 2003). RAPD analysis may be used for many plant samples, using small quantities to study molecular mapping, taxonomy and phylogeny and genetic diversity. It is also used successfully for both the identification and classification of plant cultivars (Li et al., 2006). Furthermore, RAPD is effective, simple and more rapid compared to other molecular methods that use small oligonucleotides that differ in their DNA sequence (Shehata, 2004).

In the present study, the extent of genetic diversity between 12 minor and major populations of Vicia faba L. collected from some area of Tunisia was assessed by using morphological and molecular markers.

\section{MATERIAL AND METHODS}

\section{Plant materials}

We used twelve populations of $V . f a b a$, three major (Mateur, Alia, and Eljem) and seven minor (Mateur, Takelsa, Korba, Fahes, Eljem, Mahdia, and Ltaifia), collected from different regions in Tunisia during 2010, and two reference varieties Locale and Saber 02 (Table1). 
Table 1. Bioclimatic characteristic of the collection sites of Tunisian populations of Vicia faba L.

\begin{tabular}{|c|c|c|c|c|c|}
\hline Population code & Location & Altitude (m) & Latitude & Longitude & Rainfall (mm/year) \\
\hline 1 & Mateur & 51 & 37.04 & 9.66 & $550-600$ \\
\hline 2 & Alia & 42 & 37.16 & 9.98 & $450-550$ \\
\hline 3 & Takelsa & 168 & 36.81 & 10.66 & $500-600$ \\
\hline 4 & Korba & 52 & 36.61 & 10.81 & $450-500$ \\
\hline 5 & Fahes & 170 & 36.36 & 9.90 & $350-550$ \\
\hline 6 & Eljem & 107 & 35.30 & 10.71 & $200-300$ \\
\hline 7 & Mahdia & 11 & 35.50 & 10.95 & $200-300$ \\
\hline 8 & Ltaifia & 13 & 34.74 & 10.76 & $200-250$ \\
\hline 9 & Locale & ND & ND & ND & ND \\
\hline 10 & Saber 02 & ND & ND & ND & ND \\
\hline
\end{tabular}

ND: Not Determined.

\section{Morphological traits}

Twelve genotypes of $V$. $f a b a$ were analyzed. To account for environmental variance, fifteen seeds per genotype were used. A total of 180 plants were studied. Seeds were surface sterilized with $\mathrm{HgCl}_{2}(0.2 \%)$ for 3 min and rinsed 10 times with sterile-distilled water. Soaked seeds were sown in Petri dishes on $0.9 \%$ agar. Besides, seedlings were transplanted in plastic pots, which were placed in a greenhouse at the Biotechnology Centre of Borj Cedria (CBBC).

Eleven morphological traits related to the different developmental phases of plants were measured (Table 2). For dry weight determination, plant organs were dried at $70^{\circ} \mathrm{C}$ for $48 \mathrm{~h}$.

Table 2. List of morphological traits measured and their abbreviations.

\begin{tabular}{ll}
\hline Trait & Abbreviation \\
\hline Plant height $(\mathrm{cm})$ & PlH \\
Number of flowers & NFl \\
Aerial fresh weight $(\mathrm{g})$ & AFW \\
Aerial dry weight $(\mathrm{g})$ & ADW \\
Length of roots $(\mathrm{cm})$ & LR \\
Number of nodule & NNod \\
Root fresh weight $(\mathrm{g})$ & RFW \\
Root dry weight $(\mathrm{g})$ & RDW \\
Number of pods & NP \\
Number of seeds & NS \\
Weight of 100 seeds $(\mathrm{g})$ & W100S \\
\hline
\end{tabular}

\section{Molecular traits}

\section{DNA extraction}

Total genomic DNA from the young leaves was isolated following the modified method of Geuna (2004). Ten plants from each population were used in this experiment. DNA was quantified spectrophotometrically by taking the absorbance at $260 \mathrm{~nm}$ using a Biophotometer. The quality of the DNA was estimated on an agarose gel $(0.8 \%)$ stained with ethidium bromide. 


\section{Amplification reactions}

Polymerase chain reaction (PCR) amplification of DNA was performed with each of seven decamer primers obtained from Operon Technologies: P4 (GTTAGGTCGT); P6 (TCG CCCCATT); P8 (GTCCCGTTAC); P11 (CTGTGCTGTG); P105 (CAGTCGCGTG); P137 (ATCTGCGACA), and Cs12 (GCGACGCCTA).

PCR was performed in a $20-\mu \mathrm{L}$ reaction mixture containing 20 to 40 ng DNA template, $2 \mu \mathrm{L} \mathrm{10X}$ reaction buffer, $2 \mu \mathrm{L} 10 \mu \mathrm{M}$ primer, $2.5 \mathrm{Mm}$ dNTPs, $25 \mathrm{mM} \mathrm{MgCl}_{2}$ and 1.5 $\mathrm{U}$ Taq polymerase. To reach the expected goals, amplifications were carried out in a Biometra thermal cycler for $3 \mathrm{~min}$ at $94^{\circ} \mathrm{C}$, followed by 40 cycles of $30 \mathrm{~s}$ at $36^{\circ} \mathrm{C}, 1 \mathrm{~min}$ at $72^{\circ} \mathrm{C}$, and 18 s at $94^{\circ} \mathrm{C}$, and a final extension for $8 \mathrm{~min}$ at $72^{\circ} \mathrm{C}$.

These amplification products were separated by electrophoresis in $1.5 \%$ agarose gels made with 1X TAE buffer ( $\mathrm{pH} 8$ ), which were stained with ethidium bromide and visualized under UV light. As a size marker, a 100-bp DNA Ladder (Promega) was run in each gel.

\section{Data analysis}

Data were subjected to analysis of variance (ANOVA) using the STATISTICA software system and the means of morphological traits measured were compared between populations with the HSD Tukey test.

RAPD markers were scored as present (1) or absent (0). A data matrix based on all the observed bands was constructed.

On the basis of the binary matrix obtained, genetic diversity indices [the percentage of polymorphic bands, the observed number of alleles $\left(N_{\mathrm{A}}\right)$, the expected number of alleles $\left(N_{\mathrm{E}}\right)$, and Shannon's information index of diversity $\left.(I)\right]$ were calculated by POPGENE 1.32 (1997). Nei's genetic differentiation index $\left[G_{\mathrm{ST}}=\left[\left(H_{\mathrm{T}}-H_{\mathrm{S}}\right) / H_{\mathrm{T}}\right]\right)$ and gene flow $\left[N_{\mathrm{m}}=0.5\left(1-G_{\mathrm{ST}}\right) / G_{\mathrm{ST}}\right]$ were calculated using the population mean diversity and the total diversity indices $\left(H_{\mathrm{S}}\right.$ was the population mean of Nei's diversity index, and $H_{\mathrm{T}}$ was the total of Nei's diversity index).

\section{RESULTS}

\section{Morphological diversity}

There was a remarkable difference between the three major populations of $V$. faba for the morphological traits (Table 3).

The Eljem and Mateur populations showed remarkable similarity for ten of eleven morphological traits. The Alia population differed from other populations by plant height, number of flowers, aerial fresh weight, aerial dry weight, length of roots, number of nodules, root fresh weight and root dry weight. Alia showed similarity for seed yield which could be increased by inoculation (Table 3 ).

The nine minor populations of $V$. faba exhibited considerable variation for most of the morphological characters (Table 4). It can be seen from the results that there was a remarkable similarity between the Korba, Mateur, and Takelsa populations for most of the morphological traits. The Eljem population had the highest seed yield (Table 4). 
Table 3. Means of morphological traits measured of three major populations of Vicia faba used in this study.

\begin{tabular}{|c|c|c|c|c|c|c|c|c|c|c|c|}
\hline Populations & $\mathrm{PlH}$ & N Fl & AFW & ADW & LR & NNod & RFW & RDW & NP & NS & W100S \\
\hline Mateur & $59.5^{b}$ & $56.5^{\mathrm{a}}$ & $118.25^{\mathrm{a}}$ & $15.75^{\mathrm{a}}$ & $58^{\mathrm{a}}$ & $180.5^{\mathrm{a}}$ & $44.75^{\mathrm{a}}$ & $2.80^{\mathrm{a}}$ & $2.33^{\mathrm{a}}$ & $2.55^{\mathrm{a}}$ & $198.97^{\mathrm{a}}$ \\
\hline Alia & $65.25^{\mathrm{b}}$ & $19.75^{\mathrm{b}}$ & $54.5^{\mathrm{b}}$ & $6.25^{\mathrm{b}}$ & $24.75^{\mathrm{c}}$ & $92.5^{\mathrm{b}}$ & $16.25^{\mathrm{b}}$ & $1.33^{\mathrm{b}}$ & $2.11^{\mathrm{a}}$ & $2.88^{\mathrm{a}}$ & $191.07^{\mathrm{a}}$ \\
\hline Eljem & $79.25^{\mathrm{a}}$ & $54.75^{\mathrm{a}}$ & $120.75^{\mathrm{a}}$ & $15.69^{\mathrm{a}}$ & $39.75^{\mathrm{b}}$ & $189^{\mathrm{a}}$ & $47.5^{\mathrm{a}}$ & $3.28^{\mathrm{a}}$ & $2.33^{\mathrm{a}}$ & $3.11^{\mathrm{a}}$ & $179.91^{\mathrm{a}}$ \\
\hline
\end{tabular}

Means in each column having similar letters are not significantly different using HSD Tukey test at 5\% level.

Table 4. Means of morphological traits measured of nine minor populations of Vicia faba used in this study.

\begin{tabular}{|c|c|c|c|c|c|c|c|c|c|c|c|}
\hline Populations & $\mathrm{PlH}$ & N F1 & AFW & ADW & LR & NNod & RFW & RDW & NP & NS & W100S \\
\hline Eljem & $79.25^{\mathrm{c}}$ & 25.5 & $89.00^{\mathrm{bc}}$ & $11.25^{\mathrm{b}}$ & $59.50^{\mathrm{ab}}$ & $112.75^{\mathrm{a}}$ & $33.50^{\mathrm{a}}$ & $1.64^{\mathrm{d}}$ & $2.83^{b}$ & $5.50^{\mathrm{b}}$ & $144.25^{\mathrm{a}}$ \\
\hline Saber02 & $101.75^{\mathrm{a}}$ & 4 & $66.75^{\mathrm{d}}$ & $7.625^{\mathrm{cd}}$ & $33.75^{\mathrm{c}}$ & $56.25^{\mathrm{c}}$ & $19.31^{\mathrm{c}}$ & $1.54^{\mathrm{de}}$ & $5.16^{\mathrm{ab}}$ & $11.66^{\mathrm{ab}}$ & $47.28^{\mathrm{b}}$ \\
\hline Fahes & 81.7 & 68.5 & $81.25^{\mathrm{cd}}$ & $11.25^{\mathrm{b}}$ & $66.50^{\mathrm{a}}$ & $123.25^{\mathrm{a}}$ & $30.50^{\mathrm{ab}}$ & $2.46^{\mathrm{bc}}$ & $4.00^{\mathrm{b}}$ & $10.00^{\mathrm{b}}$ & $42.87^{\mathrm{b}}$ \\
\hline Mahdia & $83.25^{\mathrm{c}}$ & $23.25^{\mathrm{c}}$ & $111.50^{\mathrm{a}}$ & $12.50^{\mathrm{ab}}$ & $52.75^{\mathrm{b}}$ & $115.25^{\mathrm{a}}$ & $22.75^{\mathrm{bc}}$ & $2.02^{\mathrm{cd}}$ & $2.00^{\mathrm{b}}$ & $3.33^{\mathrm{b}}$ & $91.22^{\mathrm{a}}$ \\
\hline Ltaifia & $63.25^{\mathrm{d}}$ & $15.75^{\mathrm{c}}$ & $42.25^{\mathrm{e}}$ & $3.69^{\mathrm{e}}$ & $24.75^{\mathrm{c}}$ & $81.50^{\mathrm{b}}$ & $4.57^{\mathrm{d}}$ & $0.57^{\mathrm{f}}$ & $2.66^{\mathrm{b}}$ & $3.50^{\mathrm{b}}$ & $78.23^{\mathrm{b}}$ \\
\hline Korba & $77.50^{\mathrm{c}}$ & $77.50^{\mathrm{a}}$ & $101.50^{\mathrm{ab}}$ & $15.25^{\mathrm{a}}$ & $54.25^{\mathrm{b}}$ & $89.25^{\mathrm{b}}$ & $36.40^{\mathrm{a}}$ & $3.66^{\mathrm{a}}$ & $7.83^{\mathrm{ab}}$ & $14.16^{\mathrm{ab}}$ & $50.96^{\mathrm{b}}$ \\
\hline Mateur & $86.25^{\mathrm{bc}}$ & $68.00^{\mathrm{a}}$ & $113.00^{\mathrm{a}}$ & $12.50^{\mathrm{ab}}$ & $50.25^{\mathrm{b}}$ & $59.50^{\mathrm{c}}$ & $33.68^{\mathrm{a}}$ & $2.40^{\mathrm{bc}}$ & $12.66^{\mathrm{a}}$ & $30.83^{\mathrm{a}}$ & $41.02^{\mathrm{b}}$ \\
\hline Takelsa & $96.5^{\mathrm{ab}}$ & $50.00^{\mathrm{b}}$ & $103.00^{\mathrm{ab}}$ & $9.75^{\mathrm{bc}}$ & $57.50^{\mathrm{ab}}$ & $107.75^{\mathrm{a}}$ & $32.09^{\mathrm{a}}$ & $2.97^{\mathrm{b}}$ & $8.83^{\mathrm{ab}}$ & $21.33^{\mathrm{ab}}$ & $49.05^{\mathrm{b}}$ \\
\hline Locale & $78.00^{\mathrm{c}}$ & $12.66^{\mathrm{c}}$ & $73.66^{\mathrm{cd}}$ & $5.41^{\mathrm{de}}$ & $31.33^{\mathrm{c}}$ & $48.66^{\mathrm{c}}$ & $6.18^{d}$ & $0.84^{\mathrm{ef}}$ & $5.33^{\mathrm{ab}}$ & $13.00^{\mathrm{ab}}$ & $45.18^{\mathrm{b}}$ \\
\hline
\end{tabular}

Means in each column having similar letters are not significantly different using HSD Tukey test at 5\% level.

\section{RAPD genetic diversity}

For all the populations, a total of 218 RAPD fragments were amplified with 7 selected primers (Table 5), in a size range of 100-2700 bp, with 218 polymorphic bands (100\%). The number of bands produced by each primer varied from 23 (CS12) to 36 (P11), with an average of 31 . With a $95 \%$ threshold, the percentage of polymorphism ranged from $62.86(\mathrm{P} 4)$ to $92.59 \%$ (P6), with an average of $75.96 \%$. The Cs 12 primer also showed a substantial percentage of polymorphism $(86.96 \%)$.

The level of polymorphism within a population ranged from 32.11 (Mahdia and Ltaifia populations) to $51.38 \%$ (Takelsa and Locale populations), showing that the Takelsa and Locale populations were the most polymorphic. Several genetic diversity indices were measured: the observed number of alleles $\left(N_{\mathrm{A}}\right)$, the effective number of alleles $\left(N_{\mathrm{E}}\right)$, gene diversity $(H)$ and Shannon Information index $(I)$ (Table 6).

Table 5. RAPD primers and bands produced for Tunisian populations of Vicia faba L.

\begin{tabular}{lcccc}
\hline Primers & Total no. of bands & No. of polymorphic bands & No. of monomorphic bands & Polymorphism (\%) \\
\hline P4 & 35 & 22 & 13 & 62.86 \\
P6 & 27 & 25 & 2 & 7 \\
P8 & 27 & 20 & 12 & 74.59 \\
P11 & 36 & 24 & 10 & 66.67 \\
P105 & 35 & 25 & 8 & 71.43 \\
P137 & 35 & 27 & 3 & 77.14 \\
CS12 & 23 & 20 & 55 & - \\
Total & 218 & 163 & 8 & 76.96 \\
Means & 31 & 23 & & 75.96 \\
\hline
\end{tabular}


Table 6. Genetic diversity for RAPD primers.

\begin{tabular}{lccccc}
\hline Primer & Simple size & $N_{\mathrm{A}}{ }^{*}$ & $N_{\mathrm{E}}{ }^{*}$ & $H^{*}$ & $I^{*}$ \\
\hline P4 & 120 & 2 & 1.17 & 0.13 & 0.23 \\
P6 & 120 & 2 & 1.26 & 0.18 & 0.31 \\
P8 & 120 & 2 & 1.18 & 0.14 & 0.25 \\
P11 & 120 & 1.26 & 0.17 & 0.28 \\
P105 & 120 & 2 & 1.2 & 0.14 & 0.25 \\
P137 & 120 & 2 & 1.31 & 0.21 & 0.34 \\
Cs12 & 120 & 2 & 1.45 & 0.27 & 0.42 \\
Mean & 120 & 0 & 0.26 & 0.17 & 0.29 \\
SD & & 27 & 0.15 & 0.2 \\
\hline
\end{tabular}

$* N_{\mathrm{A}}=$ Observed number of alleles. $* N_{\mathrm{E}}=$ Effective number of alleles [Kimura and Crow (1964)]. * $H=$ Nei's (1978) gene diversity. ${ }^{*} I=$ Shannon's Information index [Lewontin (1972)].

$N_{\mathrm{A}}$ was 2. $N_{\mathrm{E}}$ ranged from $1.17(\mathrm{P} 4)$ to 1.45 (Cs12), with a mean of $1.26 . H$ varied from $0.13(\mathrm{P} 4)$ to $0.27(\mathrm{Cs} 12)$ with a mean of 0.17 . I ranged from $0.23(\mathrm{P} 4)$ to 0.42 (Cs12), with a mean of 0.29 . Hence, the results showed that Cs12 revealed a high level of genetic variation.

The Takelsa, Fahes, and Locale populations showed the highest Nei's genetic diversity and Shannon's information index ( 0.13 and 0.21 , respectively), while the Ltaifia population showed the lowest values ( 0.08 and 0.13 , respectively).

The average gene diversity within population was $0.16\left(H_{\mathrm{S}}\right)$ and within total population $0.17\left(H_{\mathrm{T}}\right)$. Investigations proved that genetic differentiation between populations $\left(G_{\mathrm{ST}}\right)$ had an mean of 0.06 , indicating a moderate level of genetic differentiation between the populations of $V$. faba L analyzed. Gene flow $\left(N_{\mathrm{m}}\right)$ was found to be 8.21 , indicating notable gene flow between populations (Table 7). Nei's genetic distances ranged from 0.028 (between F Alia and F Mateur) to 0.131 (between F Eljem and Ltaifia), with a mean of 0.079 (Table 8).

From the UPGMA dendrogram (Figure 1), it was discernible that the Ltaifia (LT) and Mahdia (MH) populations were the most distant and clustered separately from other populations of $V$. faba, which were grouped into two main clusters, cluster I (CI) grouped the major populations and cluster II (CII) contained minor populations. Interestingly, cluster (CI) appeared separately from second cluster (CII), showing a high level of genetic variation between major and minor populations of $V$. faba. The first one was made up of three populations of $V$. faba major: Eljem (FEJ), Alia (FA) and Mateur (FM).

Cluster II showed a high level of diversity and it was further divided into two subclusters. Subcluster I (ScI) had five samples [Saber02 (SB), Locale (LC), Fahes (FH), Eljem (EJ) and Takelsa (TK)]. Subcluster II was found to contain two samples [Mateur (MT) and $\operatorname{Korba}(\mathrm{KB})]$.

\section{Table 7. Genetic diversity index.}

\begin{tabular}{lccccc}
\hline Locus & Sample Size & $H_{\mathrm{T}}$ & $H_{\mathrm{S}}$ & $G_{\mathrm{ST}}$ & $N_{\mathrm{m}}\left(G_{\mathrm{ST}}\right)^{*}$ \\
\hline Mean & 120 & 0.1730 & 0.1631 & 0.0574 & 8.2127 \\
St. Dev & & 0.0214 & 0.0187 & \\
\hline$H_{\mathrm{T}}=$ total variability. $H_{\mathrm{S}}=$ variability & within population. $G_{\mathrm{ST}}=$ diversity among populations. $N_{\mathrm{m}}=$ gene flow $(0.5$ \\
$\left.\left(1-G_{\mathrm{ST}}\right) / G_{\mathrm{ST}}\right)$. & & &
\end{tabular}


Table 8. Nei’s genetic distances between pairwise Vicia faba L.populations.

\begin{tabular}{|c|c|c|c|c|c|c|c|c|c|c|c|c|}
\hline Parameter & Ltaifia & Takelsa & Eljem & F Alia & F Mateur & Korba & Fahes & Locale & Mahdia & Mateur & F Eljem & Saber 02 \\
\hline$\overline{\text { Ltaifia }}$ & 0 & & & & & & & & & & & \\
\hline Takelsa & 0.073 & 0 & & & & & & & & & & \\
\hline Eljem & 0.068 & 0.047 & 0 & & & & & & & & & \\
\hline F Alia & 0.084 & 0.040 & 0.055 & 0 & & & & & & & & \\
\hline F Mateur & 0.116 & 0.062 & 0.068 & 0.028 & 0 & & & & & & & \\
\hline Korba & 0.085 & 0.045 & 0.062 & 0.056 & 0.079 & 0 & & & & & & \\
\hline Fahes & 0.082 & 0.049 & 0.047 & 0.059 & 0.077 & 0.043 & 0 & & & & & \\
\hline Locale & 0.070 & 0.037 & 0.036 & 0.041 & 0.063 & 0.047 & 0.031 & 0 & & & & \\
\hline Mahdia & 0.124 & 0.086 & 0.092 & 0.085 & 0.105 & 0.072 & 0.060 & 0.068 & 0 & & & \\
\hline Mateur & 0.103 & 0.049 & 0.059 & 0.036 & 0.059 & 0.046 & 0.048 & 0.048 & 0.065 & 0 & & \\
\hline F Eljem & 0.131 & 0.070 & 0.080 & 0.052 & 0.046 & 0.075 & 0.074 & 0.073 & 0.093 & 0.064 & 0 & \\
\hline Saber 02 & 0.096 & 0.056 & 0.051 & 0.050 & 0.062 & 0.063 & 0.045 & 0.041 & 0.061 & 0.047 & 0.066 & 0 \\
\hline
\end{tabular}

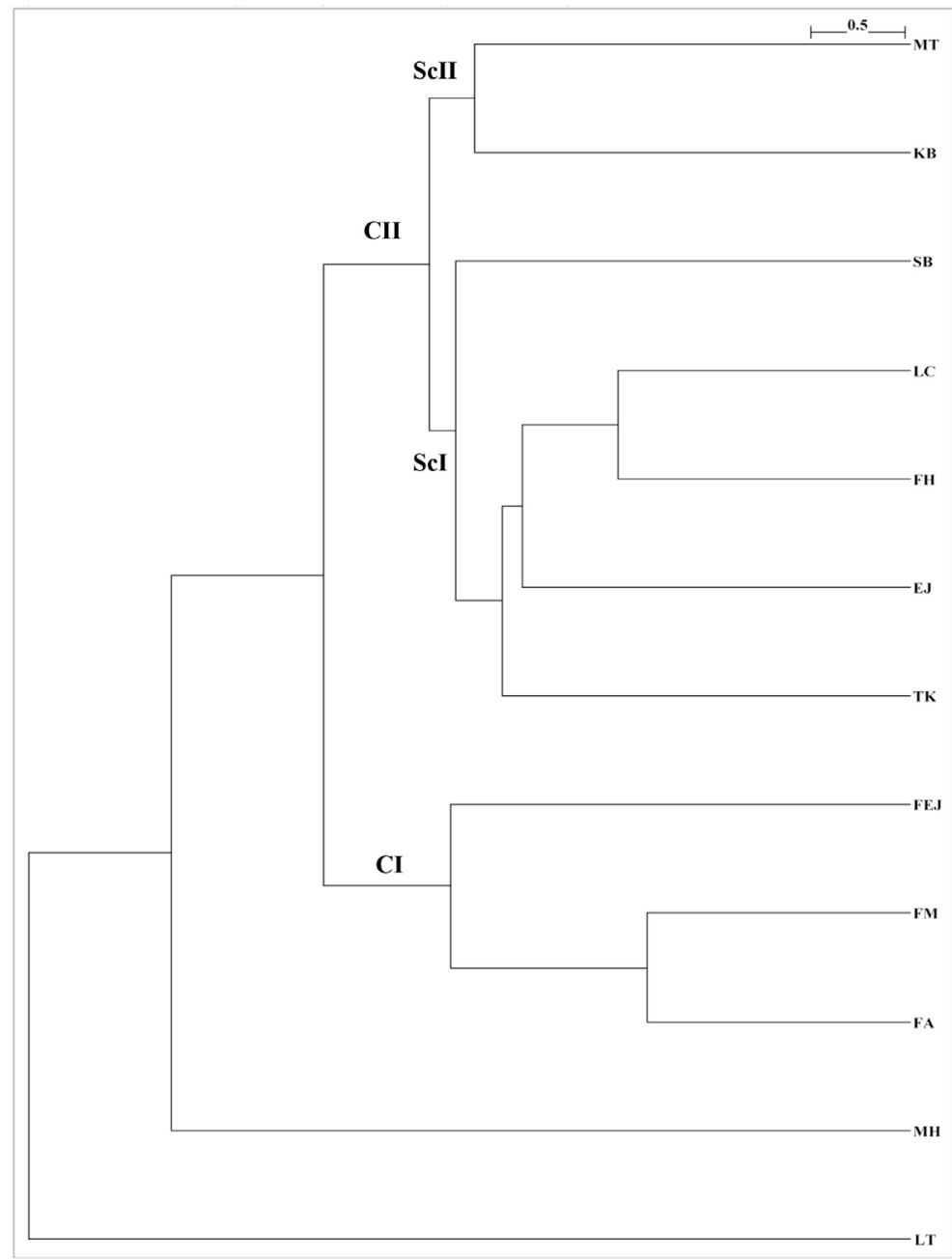

Figure 1. Dendrogram based on Nei's (1978) genetic distance: method UPGMA modified from neighbor procedure of PHYLIP version 3.5. 


\section{DISCUSSION}

Morphological traits indicated that major and minor populations of $V$. faba exhibited considerable variation. Particularly the nine $V$. faba minor populations showed considerable variation for most of the morphological characters in agreement with a previous observation describing a large diversity for morpho-agronomic traits in Greek and Ethiopian landraces (Keneni et al., 2005; Terzopoulos et al., 2008). Recently in Tunisia, Yahia et al. (2012) described a substantial phenotypic variability in faba bean germplasm using morphological descriptors. Moreover, the study showed interesting populations, such as Alia with significant gain yield despite poor nodulation. Its grain yield could be improved by efficient soil bacteria inoculation. In this context, Trabelsi et al. (2011) reported that inoculation of Phaseolus vulgaris with two indigenous rhizobia strains induced a significant increase in nodulation and grain yield.

The results obtained from RAPD analysis used to assess the genetic diversity of Tunisian $V$. faba populations showed that the primer Cs 12 was recommended to examine the genetic diversity of $V$. faba populations. Our results reflected similar findings as reported earlier in studies of the genetic variation in other species at the cultivar level by using RAPD markers (Singh et al., 2012; Kalpanaa et al., 2012; Badfar-Chaleshtori et al., 2012; Basheer-Salimia et al., 2012; Rajesha et al., 2013) and among Palestinian faba bean landraces (Basheer-Salimia et al., 2013).

Furthermore, investigations reported that the species maintained a high genetic diversity within populations. The minor populations of $V$. faba exhibited a high level of diversity and were further divided into two subclusters, which agrees with a previous study of genetic diversity in European and Mediterranean faba bean germplasm using RAPD markers (Link et al., 1995). In addition, Terzopoulos and Bebeli (2008) studied 20 local Greek faba bean populations using four ISSR primers and proposed that the majority of the observed genetic variability was due to within population variation $(75.4 \%)$.

Our results showed that genetic diversity within population was $94 \%$ of total diversity and intra-population genetic diversity $\left(H_{\mathrm{s}}\right)$ was 0.16 , which was clearly higher than between population genetic diversity $\left(D_{\mathrm{ST}}=0.06\right)$. Similarly, on the basis of AFLP analysis, Gresta et al. (2010) observed a considerable level of genetic variation within faba bean accessions. Recently, Ouji et al. (2012) demonstrated that the majority of the genetic variation of faba bean populations was found within populations.

Overall, the Ltaifia population was the most homogeneous, which can be considered a selected cultivar with very interesting agronomic characters, and this cultivar can be proposed as obtained for direct use by farmers.

In addition, the Takelsa population was the most heterogeneous which represents a interesting reservoir of genes for breeding programs.

There was agreement on a variety relationship between the morphology and molecular methods. Similar results were obtained by many authors when comparing the findings of morphological and molecular analyses in different species (Wang et al., 2002; Li et al., 2006; Talbi et al., 2008; Benor et al., 2012).

The significant positive correlations between the matrices obtained from the RAPD markers and the morphological trait matrices also indicate that morphological characters can provide a useful measure of genetic diversity between inbred lines (Ye et al., 2008). This correlation can be used to study populations efficiently in plant breeding programs. 


\section{CONCLUSIONS}

In the present study, data on morphological traits and RAPD markers used for evaluating genetic diversity in $V$. faba revealed different levels of polymorphism between populations. The primer Cs12 was recommended to examine the genetic diversity in the collections of $V$. faba populations. Our results showed that the Ltaifia population was the most homogeneous, which can be considered a selected population, and that the Takelsa population was the most heterogeneous, which is interesting for breeding program.

\section{REFERENCES}

Badfar-Chaleshtori S, Shiran B, Kohgard M, Mommenia H, et al. (2012). Assessment of genetic diversity and structure of Imperial Crown (Fritillaria imperialis L.) populations in the Zagros region of Iran using AFLP, ISSR and RAPD markers and implications for its conservation. Biochem. Systemat. Ecol. 42: 35-48.

Basheer-Salimia R, Awad M and Ward J (2012). Assessments of biodiversity based on molecular markers and morphological traits among west-bank, Palestine fig genotypes (Ficus carica L.). Am. J. Plant Sci. 3: 1241-1251.

Basheer-Salimia R, Shtaya M, Awad M, Abdallah J, et al. (2013). Genetic diversity of Palestine landraces of fababean (Vicia faba) based on RAPD markers. Genet. Mol. Res. 12: 3314-3323.

Benor S, Demissew S, Hammer K, Blattner FR (2012). Genetic diversity and relationships in Corchorusolitorius (Malvaceaes.1.) inferred from molecular and morphological data. Genet. Res. Crop Evol 59: 1125-1146.

Duc G, Bao SY, Baum M, Redden B, et al. (2010). Diversity maintenance and use of Vicia faba L. genetic resource. Field Crop. Res. 115: 270-278.

Geuna F, Toschi M and Bassi D (2003). The use of AFLP markers for cultivar identification in apricot. Plant Breed 122: 526-531.

Gichuki ST, Berenyi M, Zhang D, Hermann M, et al. (2003). Genetic diversity in sweet potato (Ipomoea atatas) in relationship to geographic source as assessed with RAPD markers. Genet. Res. Crop Evol 5: 429-437.

Gong YM, Xu SC, Mao WH, Li ZY, et al. (2011). Genetic diversity analysis of faba bean (Vicia fabaL.) based on ESTSSR markers. Agr. Sci. China 10: 838-844.

Gresta F, Avola G, Albertini E, Raggi L, et al. (2010). A study of variability in the Sicilian faba bean landrace 'Larga di Leonforte'. Gen. Resour. Crop Evol. 57: 523-531.

Kalpanaa D, Choia SH, Choia TK, Senthilb K, et al. (2012). Assessment of genetic diversity among varieties of mulberry using RAPD and ISSR fingerprinting. Sci. Hortic. 134: 79-87.

Keneni G, Jarso M, Wolabu T, Dino G (2005). Extent and pattern of genetic diversity for morpho-agronomical traits in Ethiopian highland pulse landracesII. Faba bean (Vicia faba L.). Genet. Res. Crop Evol 52: 551-561.

Kimura M and Crow JF (1964). The number of alleles that can be maintained in a finite population. Genetics 49: 725-738.

Lewontin RC (1972). The Apportionment of Human Diversity. In: Evolutionary Biology (Dobzhansky T, Hecht MK and Steere WC, eds.). 6th edn. Appleton-Century-Crofts, New York, 381-398.

Li JJ, Pei GL, Pang HX, Bilderbeck A, et al. (2006). A new method for RAPD primers selection based on primers bias in nucleotide sequence data. J. Biotechnol 126: 415-423.

Link W, Dixkens C, Singh M, Schwall M, et al. (1995). Genetic diversity in European and Mediterrenean faba bean germ plasm revealed by RAPD markers. Theor. Appl. Genet 90: 27-32.

Nei M (1978). Estimation of average heterozygosity and genetic distance from a small number of individuals. Genetics 89: $583-590$.

Ouji A, El Bok S, Syed NH, Abdellaoui R, et al. (2012). Genetic diversity of faba bean (Vicia faba L.) populations revealed by sequence specific amplified polymorphism (SSAP) markers. Afr. J. Biotechnol. 11: 2162-2168.

Rajesha MK, Jerarda BA, Preethia P, Thomasb RJ, et al. (2013). Development of a RAPD-derived SCAR marker associated with tall-type palm trait in coconut. Sci. Hortic. 150: 312-316.

Shehata MM (2004). The roles of seed protein and RAPD-PCR in genotyping variability's of some wheat (Triticum vulgar) cultivars Palm. Pak. J. Biol. Sci. 7: 984-994.

Singh S, Panda MK, NayakS (2012). Evaluation of genetic diversity in turmeric (Curcuma longa L.) using RAPD and ISSR markers. Ind. Crop. Prod. 37: 284-291.

Talbi R, Fayaz F, Mardi M, Pirsyedi SM, et al. (2008). Genetic relationships among chickpea (Cicer arietinum) elite lines based on RAPD and agronomic markers. Int. J. Agri. Biol. 1814-9596-07-389.

Terzopoulos PJ and Bebeli PJ (2008). Genetic diversity analysis of Mediterranean faba bean (Vicia faba L.) with ISSR

Genetics and Molecular Research 14 (3): 7587-7596 (2015)

CFUNPEC-RP www.funpecrp.com.br 
markers. Field Crops Res 108: 39-44.

Terzopoulos PJ, Kaltsikes PJ and Bebeli PJ (2008). Determining the sources of heterogeneity in Greek faba bean local populations. Field Crops Res 105: 124-130.

Trabelsi D, Mengoni A, Ben Ammar H, Mhamdi R (2011). Effect of on-field inoculation of Phaseolus vulgaris with rhizobia on soil bacterial communities. FEMS Microbiol Ecol 77: 211-222.

Vilanova S, Badenes ML, Martinez-Calvo J, Liacer G (2001). Analysis of loquat germplasm (Eriobotrya Japonica) by RAPD molecular markers. Euphytica 121: 25-29.

Wang N, Akey JM, Zhang K, Chakraborty R, Jin L (2002). Distribution of recombination crossovers and the origin of haplotype blocks: the interplay of population history, recombination, and mutation. Am. J. Hum. Genet 71: 12271234.

Yahia Y, Guetat A, Elfalleh W, Ferchichi A, et al. (2012). Analysis of agromorphological diversity of southern Tunisia faba bean (Vicia faba L.) germplasm. Afr. J. Biotechnol. 11: 11913-11924.

Ye YM, Zhang JW, Ning GG, Bao MZ (2008). A comparative analysis of the genetic diversity between inbred lines of Zinnia elegans using morphological traits and RAPD and ISSR markers. Sci. Hort. 118: 1-7. 